\title{
The spatiality of violence in post-war cities
}

\section{Emma Elfversson, Ivan Gusic \& Kristine Höglund}

To cite this article: Emma Elfversson, Ivan Gusic \& Kristine Höglund (2019) The spatiality of violence in post-war cities, Third World Thematics: A TWQ Journal, 4:2-3, 81-93, DOI: 10.1080/23802014.2019.1675533

To link to this article: https://doi.org/10.1080/23802014.2019.1675533
(C) 2019 The Author(s). Published by Informa UK Limited, trading as Taylor \& Francis Group.

Published online: 19 Nov 2019.

Submit your article to this journal $₫$

Q View related articles $\sqsubset$

View Crossmark data $₫$ 


\title{
The spatiality of violence in post-war cities
}

\author{
Emma Elfversson (iD) ${ }^{a}$, Ivan Gusic (iD) ${ }^{b}$ and Kristine Höglund (iD ${ }^{a}$ \\ ${ }^{a}$ Department of Peace and Conflict Research, Uppsala University, Uppsala, Sweden; ${ }^{b}$ Department of Political \\ Science, Lund University, Lund, Sweden
}

\begin{abstract}
The world is urbanising rapidly and cities are increasingly held as the most important arenas for sustainable development. Cities emerging from war are no exception, but across the globe, many post-war cities are ravaged by residual or renewed violence, which threatens progress towards peace and stability. This collection of articles addresses why such violence happens, where and how it manifests, and how it can be prevented. It includes contributions that are informed by both post-war logics and urban particularities, that take intra-city dynamics into account, and that adopt a spatial analysis of the city. By bringing together contributions from different disciplinary backgrounds, all addressing the single issue of post-war violence in cities from a spatial perspective, the articles make a threefold contribution to the research agenda on violence in post-war cities. First, the articles nuance our understanding of the causes and forms of the uneven spatial distribution of violence, insecurities, and trauma within and across post-war cities. Second, the articles demonstrate how urban planning and the built environment shape and generate different forms of violence in post-war cities. Third, the articles explore the challenges, opportunities, and potential unintended consequences of conflict resolution in violent urban settings.
\end{abstract}

\section{ARTICLE HISTORY}

Received 31 August 2019

Accepted 30 September 2019

\section{KEYWORDS}

Violence

peace

urban

cities

space

post-war

\section{Introduction}

Across the globe, post-war cities constitute volatile flashpoints for renewed war and are frequent stumbling blocks in societies seeking to transition from war to peace. ${ }^{1}$ Beirut (Lebanon), Medellín (Colombia), and Monrovia (Liberia) are examples of such cities which have experienced war, no longer do, but still remain divided and contested. In addition to posing challenges in the transition from war to peace, post-war cities often function poorly as cities and constitute dangerous sites for people to live in. One central reason for the problems facing these cities is the high prevalence of post-war violence, which not only concentrates to post-war cities but also take urban forms and is unevenly distributed within them.

This collection of articles addresses the spatiality of violence in post-war cities. At the centre of attention is the intersection of urban and post-war dynamics which has implications for why, where, and how violence plays out. The articles are grounded in the recognition that post-war logics, urban particularities, and intra-city dynamics are all 
key dimensions that need to be accounted for in order to advance knowledge on the spatiality of violence in post-war cities. Post-war cities and urban violenc have been subjects of study across disciplines such as peace and conflict research, urban studies, criminology, planning, geography, economics, and social anthropology. Yet these fields have largely remained separate and conducted research without insights from each other. To bridge this gap, we bring together contributions from a range of disciplines which approach the study of violence in post-war cities from different vantage points. The merits of this approach are multifaceted since the different fields have complementary foci. Peace research, for example, has in recent years improved our understanding of the micro-dynamics of conflict-related violence and the everyday experiences of those exposed to such violence. ${ }^{2}$ Urban studies, in turn, have extensively theorised violence in the city, generating an in-depth understanding of its urban dynamics, its spatial distribution, and its effect on different political outcomes. ${ }^{3}$ Social anthropologists and criminologists have provided detailed accounts of the individual- and group-level dynamics and incentive structures that affect participation in different forms of urban violence. ${ }^{4}$

Bringing together contributions from these and other relevant disciplines, addressing the single issue of violence in post-war cities from a spatial perspective, this collection of articles: 1) nuances our understanding of the causes and forms of the uneven spatial distribution of violence, insecurities, and trauma within and across post-war cities; 2) demonstrates how urban planning and the built environment shape and generate different forms of violence and insecurities in post-war cities; and 3) explores the challenges, opportunities, and potential unintended consequences of conflict resolution in violent urban settings.

This introductory article is structured as follows. It first lays out the theoretical departure points for this collection. It then presents the individual contributions, summarises the three main ways in which they jointly advance theory and empirical knowledge, as well as elaborates on how this collection of articles moves the research agenda on violence in post-war cities forward. It concludes by exploring some important avenues for future research.

\section{Setting the stage: the post-war city, violence, and space}

The spatiality of violence in post-war cities is of critical importance to understand how violence can be prevented, for peacebuilding in post-war cities, and for understanding how the violence-exposed people living in them are affected. A growing literature emphasises that cities are becoming increasingly central in armed conflict. ${ }^{5}$ The situation on the ground in contemporary armed conflicts - with Aleppo (Syria), Mogadishu (Somalia) and Donetsk (Ukraine) all cities subjected to large-scale violence and warfare resonates with such claims. Because cities are densely populated and hold significant political, economic, and social but also symbolic value, the impact of urban warfare is often particularly high there. ${ }^{6}$ In turn, violence reduction strategies required will also be different in cities than in non-urban sites, since cities tend to be more diverse in their demographic set-up and because urban spaces are characterised by intimate contact. ${ }^{7}$

Three dimensions are important for capturing the dynamics of violence in post-war cities: the concentration of violence to post-war cities, its urban forms, and its spatially uneven distribution. First, violence tends to continue and sometimes remain high in post- 
war societies, regardless of whether the preceding war simply peters out or is formally ended through a peace agreement or ceasefire. Such violence includes both remnants from the preceding war (e.g. violence perpetrated by former warring parties or across conflict lines) and new forms of violence that rise in the aftermath of war due to poor rule of law, political vacuums, and unemployed former soldiers. ${ }^{8}$ Such post-war violence tends to concentrate to cities, a fact which is often attributed to the particularities of the urban setting. ${ }^{9}$ Cities are dense and heterogeneous; function through mixing and everyday struggles; and constitute important symbolic and actual (political, economic, social) assets in an ever-urbanising world. ${ }^{10}$ Such dynamics contribute to violence continuing and concentrating in post-war cities in several ways. Population density makes separation of antagonists impossible in urban contexts and instead forces people to live as 'intimate enemies $^{\prime 11}$ - thus causing more clashes with 'the other' in post-war cities than elsewhere. This is evident in the case of South Africa, where the transition away from apartheid and the political conflict between rival movements ANC and Inkatha, was hampered by violence taking place in large informal settlements surrounding South Africa's cities that were 'in conflict with each other, or with more established townships, or in particular, with hostel dwellers over scarce resources such as employment, land and water. ${ }^{12}$ Because of the general (and constantly accelerating) centrality of cities, different conflict parties often aim to control key urban areas. The result is that frontlines of macro-conflicts (both during war and after) often come to centre on and run through cities, with more violence usually ensuing. ${ }^{13}$ Urban micro-struggles over space inherent to the functioning of cities tend to become intertwined with macro-conflicts, aggravating existing conflict or resulting in renewed violence in post-war cities. ${ }^{14}$ The city's density and constant mixing of people also blurs the distinction between civilians, on the one hand, and security forces or insurgents, on the other hand, thereby exposing civilians in cities to more collateral violence than elsewhere. ${ }^{15}$ Finally, the combination of urban anonymity and high streams of illicit revenues (e.g. drug dealing, trafficking, smuggling) tends to attract former fighters who in post-war cities find shelter, funds, and a levelled playing field, as well as opportunities to transform into criminal groups. ${ }^{16}$

Second, urban dynamics do not only lead violence to continue and concentrate in post-war cities; they also generate specifically urban forms of violence, which are either unique to cities or play out differently than in non-urban settings. ${ }^{17}$ Due to the centrality of cities, some types of violence, such as riots and terrorist attacks are predominantly urban phenomena, quite uncommon outside of urban areas. ${ }^{18}$ Other forms of violence are not urban per se, but tend to manifest differently (in quality and/or quantity) in cities. Urban density, for example, tends to make securitisation and militarisation of space much more all-encompassing, brutally enforced, and difficult to avoid than in border regions or less densely populated areas. The attraction cities have for criminal organisations in turn means that related forms of violence tends to be much more prevalent in cities. ${ }^{19}$

Lastly, violence is distributed unevenly across micro-locations within post-war cities, with certain neighbourhoods, streets, squares, markets, or transport nodes being more vulnerable than others. ${ }^{20}$ In Johannesburg (South Africa), certain neighbourhoods are much more prone to violent crime than others; ${ }^{21}$ in Mitrovica (Kosovo), certain locations have emerged as hotspots of violent interaction; ${ }^{22}$ and in post- (and pre-) war Juba (South Sudan), violence mainly concentrated in the city's informal settlements where groups made overlapping claims to land. ${ }^{23}$ This uneven distribution is shaped by a range of 
conditions: from the location of important urban sites and the city's topography to where 'our' and 'their' part of the city meet. Thus both material features of the city as well as the nature of social interaction taking place in a particular space shape how prone a certain location is to violence. ${ }^{24}$ Yet importantly, and as this collection will show, post-war dynamics also matter for how and where violence occurs. Post-War realities are often characterised by segregation and ghettoisation, state neglect of certain areas, socioeconomic inequality, and contested reconstruction projects. Such conditions contribute to a patchy distribution of violence across the post-war city in the sense that certain streets or areas (be it for strategic and/or symbolic reasons) become much more violent than other ones. ${ }^{25}$

Taken together, these three dynamics - the concentration of violence to post-war cities, its urban forms, and its spatially uneven distribution - are critical for understanding violence in the post-war city, and serve as important points of departures for the contributions within this collection.

\section{Advancing the research agenda}

By drawing on contributions with different disciplinary grounding and a diversity in theoretical and methodological approaches, this collection of articles sheds light on several previously unexplored features of violence in post-war cities. The different contributions engage with economic explanations, social movement theory, the microsociologies of violence, and infrastructural and material approaches - to mention some theoretical entry-points. These theories are employed and illustrated using a variety of analytical approaches such as ethnography, spatial research (including imagery and photography), qualitative analysis of focus groups and interview materials, and quantitative analyses of subnational and cross-national event data. Empirically, the contributions address violence in post-war cities from across the globe, including cases studies from Africa (Mogadishu, Johannesburg), Latin America (San Salvador, Medellín), and Europe (Belfast, Bihać, Mitrovica), as well as a cross-city dataset consisting of 98 cities from the developing world.

This diversity of contributions brings different understandings and conceptualisations of violence, post-war cities, and space to the fore, emphasising the inherent ambiguity of these often contested concepts and illustrating the need for them to be critically theorised and examined rather than taken for granted. Consequently, the contributions investigate different forms of violence such as direct, structural, and criminal violence as well as the violence of borders, of uneven development, and of transitions from one political and economic system to another. They also focus on post-war cities located in stable democracies, in largely dysfunctional states, and in contested and volatile areas. Lastly, they address the spatiality of a range of phenomena such as buildings, taxi stands, and bridges as well as peacekeeping missions and protests.

Setting the stage for the different case studies, Henry Thompson takes a macro perspective on post-war cities and analyses - through a dataset consisting of 98 cities whether the risk of urban unrest after war is dependent on the way that the conflict was terminated. ${ }^{26}$ Azra Hromadžić provides a vastly different but no less intriguing approach when taking departure from the ruin of a never finished socialist-era retirement home in the post-war city of Bihać (Bosnia-Herzegovina) to explore violence against pensioners, 
youth, and migrants. ${ }^{27}$ Silvia Danielak follows a similar track when zooming in on taxi wars around transport nodes in Johannesburg (South Africa) in order to capture the continuation of violence in the post-Apartheid era. ${ }^{28}$ Emma Elfversson, Sara Lindberg Bromley, and Paul Williams, in turn, explore how violence against peacekeepers has affected the ability of peace operations to function in, and deploy across, wartorn Mogadishu (Somalia). ${ }^{29}$ Antônio Sampaio, whose analysis centres on Medellín in Colombia, then explores how the composition of city space affects whether violence continues - and how it transforms - in the transition from war to peace. ${ }^{30}$ Emma van Santen, in turn, applies a spatio-economic lens in order to analyse how the enduring and accelerating economic inequalities in San Salvador undermined the ceasefire and peace agreement between violent gangs and the El Salvadorian state. ${ }^{31}$ Brendan Murtagh, Andrew Grounds, Philip Boland, and Linda FoxRogers also build on the distinction between deprived and affluent areas to explore Belfast's (Northern Ireland) unequal peace dividend as well as what can be done to make peace work for everyone. ${ }^{32}$ Lastly, Anna Jarstad and Sandra Segall offer a refreshing contrast to the rather bleak analyses in the other contributions when uncovering how the urban frontiers of post-war Mitrovica (Kosovo) also provide opportunities for contact, cooperation, and reconciliation. ${ }^{33}$

The collection of articles advances the research agenda by offering novel theoretical and empirical insights into three main areas: the causes and forms of violence in post-war cities; how urban planning and the built environment shape urban violence; and the challenges, opportunities, and potential unintended consequences of conflict resolution measures and violence-reduction programmes in urban contexts.

\section{The multifaceted causes and forms of violence in post-war cities}

Violence is a multifaceted phenomenon, with multiple causes, layers, and manifestations. What stands clear from the collection of articles is that violence in post-war cities neither has unitary or singular causes, nor affects post-war cities evenly. In addition, urban postwar violence tends to be diverse, fluid, and ambiguous in the forms it takes. The diversity in causes and forms pertains to both direct and structural forms of violence, as well as their interconnections. Understanding these patterns is important, not least since different forms of violence require different forms of policy responses. Failure to grapple with the specific drivers of violence in a given context may lead peacebuilding initiatives to backfire while measures to address one form of violence may cause other forms to emerge. ${ }^{34}$

Speaking to these challenges, several contributions in this collection forward our understanding of the contingent nature of direct violence in post-war cities and how it is shaped by the nature and outcome of the preceding war. Thomson demonstrates that the risk of violent unrest, such as protest and riots, is significantly higher when the incumbent government has been defeated compared to other types of conflict trajectories, such as when armed conflict is concluded by a peace agreement. Sampaio in turn shows how armed actors build local urban-based power during war and the often accompanying state vacuum, with lasting legacies for patterns of criminal violence in the post-war city when the state strives to become more present in the aftermath of war. Control over urban space - particularly poorly-serviced peripheries and slums - remains attractive for non-state armed actors in the post-war era, thus creating incentives for 
continued use of coercive strategies and violent competition, even if predominant strategies may change in the face of a new strategic context. Both these contributions emphasise how strategic considerations - including shifting power relations between non-armed actors, the state and armed non-state actors, and an altered playing field due to the transition from war to peace - contribute to explaining variation in violence within and across post-war cities.

Violence is also shaped by structural conditions and constraints. Danielak demonstrates how some forms of post-apartheid cityscapes - themselves a form a structural violence - enforce contact between antagonists and thereby increase risks of direct violence such as assault and murder. Hromadžić focuses on structural forms of violence and shows how flawed economic reforms undermine the socioeconomic future of people and nurture kleptocracies. Murtagh et al. add to these insights by demonstrating how the unequal distribution of peace dividends results in violence continuing to strike unevenly, with paramilitaries (either for ideological reasons or for refocused criminal ones) still using violence to exert influence, recruit unemployed youth, and engage in criminal enterprises.

Taken together, these contributions emphasise the continuities of violence after the formal ending of war, but also point to how a range of post-war transformations reshape the causes and patterns of violence in significant ways: from clashes between armed organised actors to more fluid actor constellations, from politically-driven violence to criminal or economically-motivated coercion, and from overt contestation to more structural forms of violence. In many post-war cities, different forms of violence coexist, making efforts to address them challenging.

\section{The inescapable influence of urban planning and the built environment}

Previous research has demonstrated how the built environment and street- and cityscapes form the rise and trajectory of conflict. ${ }^{35}$ The articles here advance insight on how urban planning and the physical features of urban space shape and generate different forms of violence and insecurities in post-war cities specifically. Danielak uses the term 'infrastructural violence' to capture the continuation of identity-based conflict in Johannesburg as well as to uncover how its post-war transport infrastructure and the architecture of individual train stations along the Gautrain route produce, concentrate, and relocate violence and generate safe/unsafe spaces. As such, she demonstrates how violence can be apprehended and mediated through the built environment. Elfversson, Lindberg-Bromley and Williams' analysis of violence against peacekeepers in Mogadishu underscores how militant groups with intimate knowledge of the urban terrain can gain comparative advantage vis-à-vis intervening forces. Hromadžić in turn explores how an empty building - 'the ruin' - becomes co-constitutive of the transformation from war to post-war by both symbolising loss (emotional as well as socioeconomic) for some marginalised groups, while providing material security for other marginalised groups in both the local and global periphery. Murtagh et al. and van Santen both poignantly demonstrate how residential segregation and spatial insularity generate (continued) economic marginalisation, undermine peace processes, and distribute the peace dividend unevenly. Danielak, however, contrastingly shows that centres of economic activity (such as shopping malls, business areas, hotels etc.) also often become high-risk areas. Sampaio, in turn, 
illustrates how the architecture and layout of different urban neighbourhoods is central in whether they stimulate or undermine the transformation of conflict-related violence into criminal violence.

These insights suggest that how post-war cities are (re)built and (re)constructed in the aftermath of war are not endeavours to be undertaken lightly or without serious reflection. They occur in politically contested situations where each and every decision regarding what streets, buildings, walls to create or destroy, as well as how this is done, can have unexpected consequences. In this way, the material features of the post-war city acquire agency of their own and become co-producers in post-war transformations.

\section{The challenges and opportunities of building peace in urban settings}

The articles lastly uncover the challenges and opportunities - but also unintended consequences - of strategies aimed at promoting peace in volatile and potentially violent urban settings. Given the contested nature of post-war cities, such strategies are rarely uniformly accepted by urban constituents, thus generating legitimacy problems and potentially violent resistance. van Santen shows how the lack of transparency and inclusion of those 'outside' the target area can severely undermine and ultimately bring down locally-mediated peace agreements. Focusing on peacekeeping in a highly contested context, Elfversson, Lindberg-Bromley and Williams explore how attacks on AMISOM in Mogadishu affected the mission's ability to operate, and find that such attacks made it more difficult for peacekeepers to spread out in and patrol the city, with adverse consequences for civil-military interactions.

While these contributions illustrate, on the one hand, that high-level peace interventions can become highly contested, Jarstad and Segall, on the other hand, show how everyday interactions can provide opportunities to move towards reconciliation. Their study of how the post-war city allows people to meet and transcend differences, demonstrates that the urban space is able to rise above rather than merely generate conflict and violence. While not downplaying the still ongoing and highly potent tensions between Mitrovica's Albanian and Serb inhabitants, they show that the contact opportunities provided (and sometimes enforced) by cites lead people to, in isolated segments, return to a shared everyday. Murtagh et al. continue along the same lines and indicate how progressive, grounded, and context-sensitive local politics that invest in the least well-off communities can remedy the continuation of spatially concentrated conflict-related violence by raising living standards and enabling communities to resist paramilitaries, as well as transform segregated and socioeconomically excluded city spaces into self-sufficient communities that are reconnected with the rest of the city.

These insights stress the undeniable and unavoidable need to adapt strategies and methods aimed at promoting peace to urban settings if they are to be effective in rebuilding, reconnecting, and regenerating the post-war city. Yet they also point to how post-war cities stand able to overcome the divisions and contestations they often are viewed to exacerbate, if utilised and approached in constructive ways. 


\section{Looking ahead}

With urbanisation projected to continue - in many parts of the world at a dramatic rate research to uncover the causes, effects, and prevention of violence in post-war cities will remain a critical research and policy topic in the foreseeable future. ${ }^{36}$ The increasing importance of cities in addressing a broad set of challenges is reflected in the UN Sustainable Development Goals (SDGs) committing to make cities inclusive, safe, resilient, and sustainable. The implications for peacebuilding and development are significant: if post-war cities can be transformed into well-functioning and safe urban sites, they have the potential to play central roles in wider transitions from war to peace in conflictravaged societies - for instance, by becoming drivers of social and economic development and incubators of coexistence and mutual tolerance. ${ }^{37}$

The cross-disciplinary approach applied in this collection has contributed to shedding light to the challenges of post-war cities and potential solutions to them by generating important insights into the nature of violence in post-war cities and its spatial dimensions. It has also opened up several new avenues for research. Generally, as the contributions reflect, most research on urban dynamics and conflict are city specific studies, prompted by the need for fine-grained analyses. A cross-city and cross-country perspective, however, could offer important insights by generating more contextualised generalisations.

Future research also needs to investigate further how the processes through which the war came to a formal end shape the conditions for urban peacebuilding. While we now know more about how different war endings influence the prospect of urban violence, the strategic setting is likely to be influenced by the broader process of conflict termination, including the involvement of actors external to the conflict. A fruitful avenue for future research would also be to learn more about the intersection between legacies from the war period, in terms of the cityscape, actor constellations, and power dynamics in the city, and how the interplay provides conditions for peaceful or violent encounters. As many contributions of the collection have suggested, perceived and actual violence is very localised. An additional important topic impelled by the contributions is how legacies of structural violence can be addressed without causing new conflict - or new forms of violence - and instead promote spatial justice and reconciliation. While urbanisation trajectories are not easily altered, a post-war situation can offer new opportunities for the transformation of actors and space, with consequences for security and insecurity. Future research could continue to advance knowledge regarding under what conditions such transformations can come about and promote constructive outcomes.

\section{Notes}

1. Beall et al., "Cities and Conflict"; Björkdahl and Strömbom, Divided Cities; Bollens, Trajectories of Peace and Conflict; Brown and Ahmed, "Local Government Dissolution"; Calame and Charlesworth, Divided Cities; Gusic, Contesting Peace; and Pullan and Baillie, Locating Urban Conflicts.

2. For instance, see Björkdahl et al., Peacebuilding and Friction; Deglow, "Localized Legacies"; Mac Ginty, No War, No Peace; Nussio, "Ex-Combatants and Violence"; Pouligny, Peace Operations; Richmond, A Post-Liberal Peace; Themnér, "Commanding Abuse"; and van Baalen and Höglund, "So, the Killings Continued." 
3. E.g. Boal, "Integration and Division"; Calame and Charlesworth, Divided Cities; Davis and de Duren, Cities and Sovereignty; Pullan and Baillie, Locating Urban Conflicts; Vignal, "Destructionin-Progress"; and Winton, "Urban Violence."

4. E.g. Auyero, Bourgois, and Scheper-Hughes, Violence at the Urban Margins; Gartner and Kennedy, "War and Postwar Violence"; Morenoff, Sampson, and Raudenbush, "Neighborhood Inequality"; Moser, "Urban Violence and Insecurity"; and Vigil, "Urban Violence."

5. Graham, Cities under Siege; Kilcullen, Out of the Mountains; Sullivan and Elkus, "Command of the Cities"; and Vignal, "Destruction-in-Progress."

6. Beall et al., "Cities and Conflict."

7. Björkdahl and Strömbom, Divided Cities; Bollens, Urban Peace-Building; and Sampaio, "Before and After Urban Warfare."

8. Beall et al., "Cities and Conflict"; Branch, "Gulu in War ... and Peace?"; Deglow, "Localized Legacies"; and Muggah, "Emerging from the Shadow."

9. Esser, "The City as Arena"; Gusic, Contesting Peace; Maclean, Social Urbanism; Moser and Mcilwaine, "New Frontiers"; and Muggah and Krause, "Closing the Gap."

10. Bollens, Trajectories of Peace and Conflict; Brenner, Implosions/Explosions; Butcher, "Geography"; Büscher, "African Cities and Violent Conflict"; and Gusic, Contesting Peace.

11. Bollens, Urban Peace-Building, 8.

12. Johnson, "South Africa."

13. Davis and de Duren, Cities and Sovereignty; and Esser, "Who Governs Kabul?"

14. Björkdahl and Mannergren Selimovic, "A Tale of Three Bridges"; Boal, "Integration and Division"; and Cunningham and Byrne, "Peacebuilding in Belfast."

15. Lucchi, "Between War and Peace"; and Sampaio, "Before and After Urban Warfare."

16. Graham, Cities under Siege; Kunkeler and Peters, "Coming to Town"; Méndez, "The Violence Work," 378; Richani, "State Capacity"; and Vignal, "Destruction-in-Progress."

17. Gusic, Contesting Peace; see also Elfversson and Höglund, "Violence in the City."

18. Dikeç, Urban Rage; and Savitch and Ardashev, "Urban Future."

19. Björkdahl and Gusic, "The Urbanization of War"; Graham, Cities under Siege; and Pullan, "Frontier Urbanism."

20. Bollens, Urban Peace-Building; Cunningham and Gregory, "Hard to Miss"; Moser, "Urban Violence and Insecurity"; and Rokem, Weissc and Miodownik, "Geographies of Violence."

21. Palmary, Rauch and Simpson, "Violent Crime in Johannesburg."

22. Gusic, "The Relational Spatiality."

23. McMichael, "Rethinking Access to Land."

24. Björkdahl and Buckley-Zistel, "Spatializing Peace and Conflict."

25. Cunningham and Gregory, "Hard to Miss"; Muggah, "A Manifesto"; Robins, "At the Limits"; Vignal, "Destruction-in-Progress."

26. Thomson, "Conflict Termination."

27. Hromadžić, "Uninvited Citizens."

28. Danielak, "Navigating Urban Encounters."

29. Elfversson, Lindberg Bromley and Williams, "Urban Peacekeeping under Siege."

30. Sampaio, "The Role of Power."

31. van Santen, "Inclusive Peace Mediation."

32. Murtagh et al., "Urban Restructuring."

33. Jarstad and Segall, "Empirical Realities of Peace."

34. Berdal, "Reflections"; and Steenkamp, "In the Shadows."

35. Büscher, "African Cities and Violent Conflict."

36. UN estimates suggest that by 2050,68 percent of the world's population will live in urban areas (UN-DESA, World Urbanisation Prospects). This means that more and more people will reside in and be affected by conflict-ridden and violent post-war cities. The effects are observable not only in the urbanisation of war and violence, but also in terms of refugee streams, exposure to climate change, and many other social issues of our time (Brenner, Implosions/Explosions; Brown and Ahmed, "Local Government Dissolution," 880-881. See 
Nogueira, 'From Failed States', for a critical assessment of the discursive and policy shifts associated with these trends).

37. See e.g. Hodson, Sekulic, and Massey, "National Tolerance," 1535-1536; and Sassen, "Cities as one Site," 576.

\section{Acknowledgements}

We thank the authors contributing to this collection of articles, the other participants in the workshop on the theme in Uppsala in March 2019, the external reviewers for excellent comments, and Madeleine Hatfield at Third World Thematics for outstanding editorial support.

\section{Funding}

We acknowledge funding from Formas [grant 2016-00290], the Swedish Research Council [grant 2018-03924], Uppsala Forum for Peace, Democracy and Justice (Uppsala University), and Grace and Philip Sandblom Foundation (Lund University).

\section{Notes on contributors}

Emma Elfversson is postdoctoral researcher at the Department of Peace and Conflict Research, Uppsala University. Her research interests concern rural/urban dimensions of organised violence, ethnic politics and communal conflict, and the role of state and non-state actors in addressing conflicts. Her recent work is published in Comparative Political Studies, Ethnopolitics, Urban Studies, and Conflict, Security and Development.

Ivan Gusic is postdoctoral researcher at the Department of Political Science, Lund University. His research interests include war-to-peace transitions in post-war cities; urban conflict and violence; and the spatiality of war and peace. Ivan's research appears in Journal of Development and International Relations, Peacebuilding and Political Geography, among others, as well as in the monograph Contesting Peace in the Postwar city: Belfast, Mitrovica and Mostar (Palgrave).

Kristine Höglund is Professor of Peace and Conflict Research at Uppsala University. She works on the causes and consequences of electoral violence; urban conflict, violence and conflict resolution; and the dynamics of peace processes, peacebuilding and transitional justice. Her research appears in Urban Studies, British Journal of Political Science, Journal of Modern African Studies and Review of International Studies, among others.

\section{ORCID}

Emma Elfversson (iD http://orcid.org/0000-0001-5673-9056

Ivan Gusic (iD http://orcid.org/0000-0003-1714-7634

Kristine Höglund (D) http://orcid.org/0000-0001-7167-609X

\section{Bibliography}

Auyero, J., P. Bourgois, and N. Scheper-Hughes, eds. Violence at the Urban Margins. New York: Oxford University Press, 2015.

Beall, J., T. Goodfellow, and D. Rodgers. "Cities and Conflict in Fragile States in the Developing World." Urban Studies 50, no. 15 (2013): 3065-3083. doi:10.1177/0042098013487775. 
Berdal, M. "Reflections on Post-War Violence and Peacebuilding." In The Peace in Between: Post-War Violence and Peacebuilding, edited by M. Berdal and A. Suhrke, 309-326. London: Routledge, 2012.

Björkdahl, A., and S. Buckley-Zistel. "Spatializing Peace and Conflict: An Introduction." In Spatializing Peace and Conflict: Mapping the Production of Places, Sites and Scales of Violence, edited by A. Björkdahl and S. Buckley-Zistel, 1-22. Basingstoke: Palgrave, 2016.

Björkdahl, A., and I. Gusic. 'The Urbanization of War: Linking Urban Violence to Armed Conflict.' Last presented at EISA, Sofia, 14 September 2019.

Björkdahl, A., K. Höglund, G. Millar, J. van der Lijn, and W. Verkoren, eds. Peacebuilding and Friction: Global and Local Encounters in Post-Conflict Societies. London/New York: Routledge, 2016.

Björkdahl, A., and L. Strömbom. Divided Cities: Governing Diversity. Lund: Nordic Academic Press, 2015.

Björkdahl, A., and J. M. Selimovic. "A Tale of Three Bridges: Agency and Agonism in Peace Building." Third World Quarterly 37, no. 2 (2016): 321-335. doi:10.1080/01436597.2015.1108825.

Boal, F. W. "Integration and Division: Sharing and Segregating in Belfast." Planning Practice and Research 11, no. 2 (1996): 151-158. doi:10.1080/02697459650036305.

Bollens, S. A. Urban Peace-Building in Divided Societies: Belfast and Johannesburg. Boulder: Westview Press, 1999.

Bollens, S. A. Trajectories of Peace and Conflict: Jerusalem and Belfast since 1994. New York: Routledge, 2018.

Branch, A. "Gulu in War ... and Peace? the Town as Camp in Northern Uganda." Urban Studies 50, no. 15 (2013): 3152-3167. doi:10.1177/0042098013487777.

Brenner, N., ed. Implosions/Explosions: Towards a Study of Planetary Urbanization. Berlin: Jovis, 2014.

Brown, A., and S. Ahmed. "Local Government Dissolution in Karachi: Chasm or Catalyst?" Third World Thematics: A TWQ Journal 1, no. 6 (2016): 879-897. doi:10.1080/23802014.2016.1315318.

Büscher, K. "African Cities and Violent Conflict: The Urban Dimension of Conflict and Post Conflict Dynamics in Central and Eastern Africa." Journal of Eastern African Studies 12, no. 2 (2018): 193-210. doi:10.1080/17531055.2018.1458399.

Butcher, C. "Geography and the Outcomes of Civil Resistance and Civil War." Third World Quarterly 38, no. 7 (2017): 1454-1472. doi:10.1080/01436597.2016.1268909.

Calame, J., and E. Charlesworth. Divided Cities: Belfast, Beirut, Jerusalem, Mostar, and Nicosia. Philadelphia: University of Pennsylvania Press, 2009.

Cunningham, C., and S. Byrne. "Peacebuilding in Belfast: Urban Governance in Polarized Societies." International Journal on World Peace 23, no. 1 (2006): 41-73.

Cunningham, N., and I. Gregory. "Hard to Miss, Easy to Blame? Peacelines, Interfaces and Political Deaths in Belfast during the Troubles." Political Geography 40 (2014): 64-78. doi:10.1016/j. polgeo.2014.02.004.

Danielak, S. "Navigating Urban Encounters: An Infrastructural Perspective on Violence in Johannesburg's Taxi Industry." Third World Thematics: A TWQ Journal 4, no. $02-03$ (2019): 137157. doi:10.1080/23802014.2019.1647795.

Davis, D. E., and N. L. de Duren, eds. Cities and Sovereignty: Identity Politics in Urban Spaces. Bloomington: Indiana University Press, 2011.

Deglow, A. "Localized Legacies of Civil War: Postwar Violent Crime in Northern Ireland." Journal of Peace Research 53, no. 6 (2016): 786-799. doi:10.1177/0022343316659692.

Dikeç, M. Urban Rage: The Revolt of the Excluded. New Haven: Yale University Press, 2017.

Elfversson, E., S. L. Bromley, and P. Williams. "Urban Peacekeeping under Siege: Attacks on African Union Peacekeepers in Mogadishu, 2007-2009." Third World Thematics: A TWQ Journal 4, no. 02-03 (2019): 158-178. doi:10.1080/23802014.2019.1678399

Elfversson, E., and H. Kristine. "Violence in the City that Belongs to No One: Urban Distinctiveness and Interconnected Insecurities in Nairobi (kenya)." Conflict, Security \& Development 19, no. 4 (2019): 347-370. doi:10.1080/14678802.2019.1640493.

Esser, D. "The City as Arena, Hub and Prey: Patterns of Violence in Kabul and Karachi." Environment and Urbanization 16, no. 2 (2004): 31-38. 
Esser, D. 'Who Governs Kabul? Explaining Urban Politics in a Post-War Capital City.' Working Paper No. 43 (series 2), London, UK; Crisis States Research Centre, 2009.

Gartner, R., and L. Kennedy. "War and Postwar Violence." Crime and Justice 47, no. 1 (2018): 1-67. doi:10.1086/696649.

Graham, S. Cities under Siege: The New Military Urbanism. London: Verso, 2010.

Gusic, I. Contesting Peace in the Postwar City: Belfast, Mitrovics, and Mostar. Basingstoke: Palgrave, 2019. (forthcoming).

Gusic, I. "The Relational Spatiality of the Postwar Condition: A Study of the City of Mitrovica." Political Geography 71 (2019): 47-55. doi:10.1016/j.polgeo.2019.02.009.

Hodson, R., D. Sekulic, and G. Massey. "National Tolerance in the Former Yugoslavia." American Journal of Sociology 99, no. 6 (1994): 1534-1558. doi:10.1086/230453.

Hromadžić, A. "Uninvited Citizens: Violence, Spatiality and Urban Ruination in Postwar and Postsocialist Bosnia and Herzegovina." Third World Thematics: A TWQ Journal 4, no. 02-03 (2019): 114-136. Published online 29 Aug 2019. doi:10.1080/23802014.2019.1646615.

Jarstad, A., and S. Segall. "Grasping the Empirical Realities of Peace in Post-War Northern Mitrovica." Third World Thematics: A TWQ Journal 4, no. 02-03 (2019): 239-259. doi:10.1080/ 23802014.2019.1687012

Johnston, A. "South Africa: The Election and the Transition Period - Five Contradictions in Search of Resolution." Third World Quarterly 15, no. 2 (1994): 187-204. doi:10.1080/ 01436599408420374.

Kilcullen, D. Out of the Mountains: The Coming Age of the Urban Guerrilla. London: Hurst, 2013.

Kunkeler, J. B., and K. Peters. "'the Boys are Coming to Town": Youth, Armed Conflict and Urban Violence in Developing Countries." International Journal of Conflict and Violence 5, no. 2 (2011): 277-291.

Lucchi, E. "Between War and Peace: Humanitarian Assistance in Violent Urban Settings." Disasters 34, no. 4 (2010): 973-995. doi:10.1111/j.1467-7717.2010.01178.x.

Mac Ginty, R. No War, No Peace: The Rejuvenation of Stalled Peace Processes and Peace Accords. New York: Palgrave, 2006.

Maclean, K. Social Urbanism and the Politics of Violence: The Medellin Miracle. Basingstoke: Palgrave, 2015.

McMichael, G. "Rethinking Access to Land and Violence in Post-War Cities: Reflections from Juba, Southern Sudan." Environment \& Urbanization 26, no. 2 (2014): 389-400. doi:10.1177/ 0956247814539431.

Méndez, M. J. "The Violence Work of Transnational Gangs in Central America." Third World Quarterly 40, no. 2 (2019): 373-388. doi:10.1080/01436597.2018.1533786.

Morenoff, J. D., R. J. Sampson, and S. W. Raudenbush. "Neighborhood Inequality, Collective Efficacy, and the Spatial Dynamics of Urban Violence." Criminology 39, no. 3 (2001): 517-558. doi:10.1111/ j.1745-9125.2001.tb00932.x.

Moser, C. "Urban Violence and Insecurity: An Introductory Roadmap." Environment \& Urbanization 16, no. 2 (2004): 3-16. doi:10.1177/095624780401600220.

Moser, C., and M. Cathy. "New Frontiers in Twenty-First Century Urban Conflict and Violence." Environment \& Urbanization 26, no. 2 (2014): 331-344. doi:10.1177/0956247814546283.

Muggah, R. "Emerging from the Shadow of War: A Critical Perspective on DDR and Weapons Reduction in the Post-Conflict Period." Contemporary Security Policy 27, no. 1 (2006): 190-205. doi:10.1080/13523260600603493.

Muggah, R. "A Manifesto for the Fragile City." Journal of International Affairs 68, no. 2 (2015): 19-36.

Muggah, R., and K. Krause. "Closing the Gap between Peace Operations and Post-Conflict Insecurity: Towards a Violence Reduction Agenda." International Peacekeeping 16, no. 1 (2009): 136-150. doi:10.1080/13533310802485617.

Murtagh, B., A. Grounds, P. Boland, and L. Fox-Rogers. "Urban Restructuring, Social Economics and Violence after Conflict." Third World Thematics: A TWQ Journal 4, no. 02-03 (2019): 220-238. doi:10.1080/23802014.2019.1674184

Nogueira, J. P. "From Failed States to Fragile Cities: Redefining Spaces of Humanitarian Practice." Third World Quarterly 38, no. 7 (2017): 1437-1453. doi:10.1080/01436597.2017.1282814. 
Nussio, E. "Ex-Combatants and Violence in Colombia: Are Yesterday's Villains Today's Principal Threat?" Third World Thematics: A TWQ Journal 3, no. 1 (2018): 135-152. doi:10.1080/ 23802014.2018.1396911.

Palmary, l., J. Rauch, and G. Simpson. "Violent Crime in Johannesburg." In Emerging Johannesburg: Perspectives on the Postapartheid City, edited by R. Tomlinson, R. Beauregard, L. Bremmer, and X. Mangcu, 101-122, New York: Routledge, 2014.

Pouligny, B. Peace Operations Seen from Below: UN Missions and Local People. London: Hurst, 2006.

Pullan, W. "Frontier Urbanism: The Periphery at the Centre of Contested Cities." The Journal of Architecture 16, no. 1 (2011): 15-35. doi:10.1080/13602365.2011.546999.

Pullan, W., and B. Baillie, eds. Locating Urban Conflicts: Ethnicity, Nationalism and the Everyday. Basingstoke: Palgrave Macmillan, 2013.

Richani, N. "State Capacity in Postconflict Settings: Explaining Criminal Violence in El Salvador and Guatemala." Civil Wars 12, no. 4 (2010): 431-455. doi:10.1080/13698249.2010.534630.

Richmond, O. P. A Post-Liberal Peace. London: Routledge, 2011.

Robins, S. "At the Limits of Spatial Governmentality: A Message from the Tip of Africa." Third World Quarterly 23, no. 4 (2002): 665-689. doi:10.1080/0143659022000005328.

Rokem, J., C. M. Weissc, and D. Miodownik. "Geographies of Violence in Jerusalem: The Spatial Logic of Urban Intergroup Conflict." Political Geography 66, September (2018): 88-97. doi:10.1016/j. polgeo.2018.08.008.

Sampaio, A. "Before and after Urban Warfare: Conflict Prevention and Transitions in Cities." International Review of the Red Cross 98, no. 901 (2016): 71-95. doi:10.1017/S1816383117000145.

Sampaio, A. "The Role of Power for Non-State Armed Groups in Cities: Marginalised Spaces and Transitions from Armed Conflict." Third World Thematics: A TWQ Journal 4, no. $02-03$ (2019): 179200. doi:10.1080/23802014.2019.1669487

Sassen, S. "Cities as One Site for Religion and Violence." In The Oxford Handbook of Religion and Violence, edited by M. Juergensmeyer, M. Kitts, and M. Jerryson, 455-466. Oxford: Oxford University Press, 2013.

Savitch, H. V., and G. Ardashev. "Does Terror Have an Urban Future?" Urban Studies 38, no. 13 (2001): 2515-2533. doi:10.1080/00420980120107529.

Steenkamp, C. "In the Shadows of War and Peace: Making Sense of Violence after Peace Accords." Conflict, Security \& Development 11, no. 3 (2011): 357-383. doi:10.1080/14678802.2011.593813.

Sullivan, J. P., and A. Elkus. "Command of the Cities: Towards a Theory of Urban Strategy." Small Wars Journal. (2011). https://smallwarsjournal.com/jrnl/art/command-of-the-cities-towards-a-theoryof-urban-strategy

Themnér, A. "Commanding Abuse or Abusing Command? Ex-Command Structures and Drugs in Liberia." Third World Thematics: A TWQ Journal 3, no. 1 (2018): 46-62. doi:10.1080/ 23802014.2018.1429227.

Thomson, H. "Conflict Termination, Signals of State Weakness and Violent Urban Social Disorder in the Developing World." Third World Thematics: A TWQ Journal 4, no. 02-03 (2019): 94-113. doi:10.1080/23802014.2019.1628660.

UN-DESA. 2018. World Urbanization Prospects: The 2018 Revision. United Nations, Department of Economic and Social Affairs.

van Baalen, S., and H. Kristine. "So, the Killings Continued': Wartime Mobilization and Post-War Violence in KwaZulu Natal, South Africa." Terrorism and Political Violence: 1-19. Published online 19 May 2017. doi:10.1080/09546553.2017.1318126.

van Santen, E. "Inclusive Peace Mediation in the City: Spatial Segregation of Violence and Urban Politics of "social" Inclusion in Gang Truces." Third World Thematics: A TWQ Journal 4, no. 02-03 (2019): 201-219. doi:10.1080/23802014.2019.1666029.

Vigil, J. D. "Urban Violence and Street Gangs." Annual Review of Anthropology 32, no. 1 (2003): 225-242. doi:10.1146/annurev.anthro.32.061002.093426.

Vignal, L. "Destruction-In-Progress: Revolution, Repression and War Planning in Syria." Built Environment 40, no. 3 (2014): 326-341. doi:10.2148/benv.40.3.326.

Winton, A. "Urban Violence: A Guide to the Literature." Environment \& Urbanization 16, no. 2 (2004): 165-184. doi:10.1630/0956247042309874. 